\title{
Synchronization of estrus in paca (Cuniculus paca L.): possible impacts on reproductive and productive parameters
}

\author{
Sincronização do estro em pacas (Cuniculus paca L.): \\ possíveis impactos sobre parâmetros reprodutivos e produtivos
}

\author{
Vânia Maria França RIBEIRO루 ; Rodolpho SATRAPA ${ }^{1}$; Jefferson Viana Alves DINIZ²; \\ Haline Ballestero FÊO $^{3}$; Luis Mauricio Montoya FLÓREZ ${ }^{3,4,5}$; Rafael Augusto SATRAPA; ${ }^{6}$ Eunice OBA $^{2}$ \\ ${ }^{1}$ Universidade Federal do Acre, Centro de Ciências Biológicas e da Natureza, Rio Branco - AC, Brazil \\ ${ }^{2}$ Universidade Estadual Paulista "Júlio de Mesquita Filho", Faculdade de Medicina Veterinária, \\ Departamento de Reprodução Animal, Botucatu - SP, Brazil \\ ${ }^{3}$ Universidade Estadual Paulista "Júlio de Mesquita Filho", Faculdade de Medicina Veterinária, Departamento de Clínica Veterinária, \\ Botucatu - SP, Brazil \\ ${ }^{4}$ Universidade de Caldas, Faculdade de Ciências Agrarias, Grupo de Pesquisa em Patologia Veterinária, Manizales - Caldas, Colombia \\ ${ }^{5}$ Universidad Pedagógica y Tecnológica de Colombia, GIDIMEVETZ Tunja - Boyacá, Colombia \\ ${ }^{6}$ Centro para o Melhoramento da Genética Animal do Estado de Acre, Rio Branco - AC, Brazil
}

\begin{abstract}
Estrus synchronization is a reproductive biotechnology used to improve artificial insemination or pairing through the manipulation of the estrous cycle at a desirable time. Employing this technique in captive pacas (Cuniculus paca L.) is important because it creates expectation of meeting the demand for paca meat and, consequently, reduces poaching. Thus, this research aims to verify the effect of a progestogen implant associated with two doses of eCG on the synchronization and induction of fertile estrus. Twenty-seven adult pacas were used, 18 non-pregnant females and nine males, divided into three groups. G1 and G2 females groups (treatments) received $1.5 \mathrm{mg}$ Norgestomet and were injected intramuscularly, seven days later, with $0.13 \mathrm{mg}$ of prostaglandin. After 24 hours the implants were removed and the animals immediately received $25 \mathrm{IU}$ and 50 IU of ECG intramuscularly, respectively. The mating of the three groups took place on the same days. G3 females' group (control) showed estrus on different days after D0. Females under treatment displayed estrus only after removing the implant (D8). G1, G2, and G3 pregnancy rates were 100\%, $66 \%$, and $50 \%$, respectively. Regarding births per parturition, $100 \%$ of G1 and G3 produced one offspring, while $50 \%$ of G2 produced two. Progestogen in the form of subcutaneous implants was effective in mimicking the luteal phase of the estrous cycle. After removal, implants favored the occurrence of a fertile estrus. As a conclusion, further studies must be conducted in order to establish in-depth possible association between $50 \mathrm{IU}$ of eCG, and the occurrence of twin pregnancies.
\end{abstract}

Keywords: Heat. Synchronization. Progestin. Rodent.

\section{Resumo}

A sincronização é uma biotécnica reprodutiva que melhora a porcentagem de cobertura por meio da manipulação do ciclo estral. Empregar esta biotécnica em pacas de cativeiro (Cuniculus paca L.) é importante, pois cria-se a expectativa de que a demanda pela carne seja atendida e a caça ilegal diminua. O objetivo da pesquisa foi verificar o efeito de implantes de progestágenos associados a duas doses de gonadotrofina coriônica equina (eCG) na sincronização e indução de cios férteis de pacas. Foram utilizadas 18 fêmeas não prenhas e nove machos, divididos em três grupos. Fêmeas do G1 e G2 receberam implantes com 1,5mg de Norgestomet e, sete dias depois, $0,13 \mathrm{mg}$ de prostaglandina via intramuscular (IM). No dia 8 (D8), foram retirados os implantes e G1 e G2 receberam 25 UI e 50 UI de eCG, IM, respectivamente; G3 foi o controle. O pareamento nos três grupos aconteceu nos mesmos dias. As fêmeas do G3 apresentaram cio alguns dias após o dia zero (D0). Fêmeas que receberam tratamento apresentaram cio só após a retirada do implante no dia 8 (D8). As taxas de prenhez de G1, G2 e G3 atingiram 100\%, 66\% e 50\%, respectivamente. Em relação a filhotes por parto, $100 \%$ do G1 e G3 produziram uma cria, enquanto 50\% do G2 produziram duas crias. O progestágeno do implante foi eficaz em mimetizar a fase lútea do ciclo estral. Após a remoção, o tratamento hormonal favoreceu a ocorrência de cio fértil. Outros estudos devem ser realizados a fim de estabelecer uma possível associação entre 50 UI de eCG e a ocorrência de gestações gemelares.

Palavras-chave: Cio. Sincronização. Progestina. Roedores. 


\section{Correspondence to:}

Luis Mauricio Montoya Flórez

Universidade do estado de São Paulo-UNESP, Faculdade de

Medicina Veterinária, Departamento de Clínica Veterinária,

Distrito Rubião Junior, Botucatu, SP, Brasil

E-mail: maomontoya53@yahoo.es

Received: $26 / 11 / 2015$

Approved: 11/01/2016

\section{Introduction}

The paca (Cuniculus paca L.), in Latin America, is among the most intensively hunted species due to its culinary lusciousness (MAYOR et al., 2013). In addition, being a small animal easily adapted to captivity and interacting spontaneously with humans, it is often captured to become a pet (MONTES, 2005). These aspects, associated with inappropriate land use and forest mismanagement, have almost caused extermination by a drastic animal reduction in some regions.

Paca meat production, already held in some farms and facilities, has created the perspective of a met demand, which eventually decreased poaching (SMYTHE; GUANTI, 1995; NOGUEIRA FILHO; NOGUEIRA, 1999). However, low reproductive rates characterized by females, which rarely give two offspring per birth, almost twice a year, may be discouraging factors for potential breeders.

On the other hand, the gestation period has commonly been the most controversial parameter between authors, reaching a difference between reported periods of up to 76 days. Bonilla-Morales et al. (2013), for example, cites a range of 76-101 days, while Scherf (1997) and Mayor et al. (2013) reported variations of 138-173 days and 135155 days, respectively.

According to Lameira (2002), biotechnology and the implementation of appropriate management techniques allow genetic selection, which will result in increased reproductive and productive efficiency of this animal.

Estrus synchronization is a reproductive biotechnology used to improve artificial insemination or pairing, as well as the birthing process, through the manipulation of the estrous cycle at a desirable time (HAFEZ, 2004). Through this technique, the breeder can focus on a timely labor. For instance, during low rainfall periods, pneumonia incidence and endoparasite infestations of wild animal in captivity diminishes while herds remain more homogeneous, which facilitates its management and sale.

The pharmacological regulation of the estrous cycle in domestic animals implies lifespan control of the corpus luteum. Therefore, progesterone (P4) or other progestogens are used to control ovulation time in goats, cows, sheep, and mares (HAFEZ, 2004). Progesterone, natural or synthetic, with or without pituitary gonadotropins, and extra-pituitary prostaglandin (PGF2a) have been successfully used in the synchronization and induction of fertile estrus in different species (DIAS et al., 2001; ROCHA et al., 2007; NOGUEIRA et al., 2008; MAIA JÚNIOR, 2009; MELLO; PINTO-NETO, 2009; MONREAL et al., 2009).

Currently, estrus and ovulation can already be synchronized in cyclic animals by combining progestin and luteolytic agents. Estrogen and PGF2a, or its analogue cloprostenol, are the most used (JAINUDEEN et al., 2004).

Associated to progestin and PGF2a, gonadotropins have further improved results in terms of pregnancy, since the equine chorionic gonadotropin (e.g.) stimulates the development of ovarian follicles (MONREAL et al., 2002; HAFEZ, 2004). An advantage of ECG linked to synchronization protocols is related to the hormone opportune administration during progestogen implant removal, thus saving labor for animal handling as compared to other protocols (MOREIRA et al., 2007).

In Cuniculus paca, no reports about animal response to hormone therapies used in ovulation induction protocols and estrus synchronization exist, nor about dosages needed to create an effective fertile estrus. Likewise, it is undefined whether this practice has influence on other reproductive or gestational parameters.

Therefore, this study aims at testing hormone protocols to induce and synchronize estrus in fertile pacas.

\section{Materials and Methods}

\section{Study area}

This study was approved by the Brazilian Ministry of Environment-MMA, Chico Mendes Institute for Biodiversity Conservation, under number 24669-1 (authorization for activities with scientific purpose), and developed in the wild animal breeding of Experimental Farm Catuaba, University Federal do Acre, municipality of Senador Guiomar, $30 \mathrm{~km}$ from BR - 364 highway $\left(10^{\circ}\right.$ $04^{\prime} \mathrm{S}$ and $67^{\circ} 37^{\prime} \mathrm{W}$ ). The Climate in the region is tipical of equatorial Amazon with temperatures ranging from $24.5^{\circ} \mathrm{C}$ to $32^{\circ} \mathrm{C}$ and relative humidity of $80 \%$ to $100 \%$ (ACRE, 2006). 


\section{Animals and treatment}

Twenty-seven adult pacas (18 non-pregnant multiparous females and 9 males) were used. Animals were placed in nine bays, with two females and one male each, later divided into three experimental groups: G1 and G2 (treatments), and G3 (control). Each group consisted of three animals per bay.

The diet of each animal contained fruits (386 g), grains (119 g), tubers (112 g), and vegetables (109 g), and was complemented with mineral supplement (mineral salt, base 40P, Real $\mathrm{H}$ brand) and water ad libitum.

G1 and G2 females received implants with $1.5 \mathrm{mg}$ of Norgestomet (Crestar, Intervet) in random days of the estrous cycle - half of the commercial presentation according to what has been described by Aramburo et al. (2006), which were inserted subcutaneously and dorsally $4 \mathrm{~cm}$ from the paraspinal region. In all groups, the time of progestagen implantation was considered day zero (D0). Seven days later, $0.13 \mathrm{mg}$ of prostaglandin (Ciosin, Coopers) was administered intramuscularly (i.m.). Finally, implants were removed 24 hours after the last treatment (D8). Immediately after removing the implants, females of $\mathrm{G} 1$ and $\mathrm{G} 2$ received 25 IU and 50 IU ECG (5000 Novormon), i.m., respectively. Males were introduced in the three groups on the day of progestin implant (D0).

When placing implants, each female was sedated with $1 \mathrm{ml}$ of $1 \%$ acepromazine (Acepran, Univet), i.m. After cutting the animal's hair, implant area was disinfected with povidone iodine and a subcutaneous anesthetic block was conducted with lidocaine hydrochloride (2\% lidocaine, Bravet), followed by $3 \mathrm{~cm}$ skin incision for implantation.

Cotton thread 2-0 (Ethicon) was utilized for suturing subcutaneous tissue where implant remained, exposing it

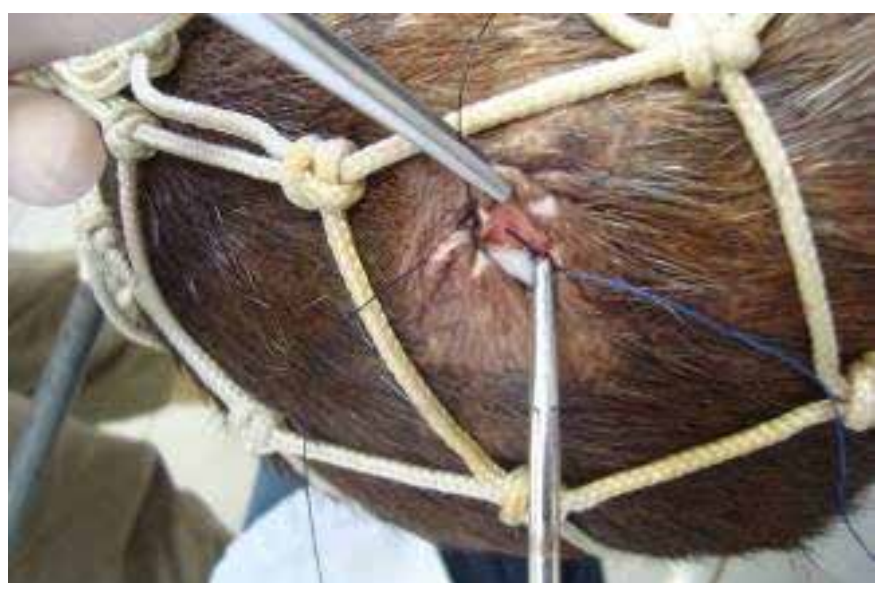

Figure 1 - Subcutaneous insertion of Crestar ${ }^{\circledast}$ in Cuniculus paca. Experimental Farm Catuaba, University Federal do Acre
$3 \mathrm{~cm}$. After healing, such excedent allowed implant to remain in control during the experiment (Figure 1). Finally, a herbal healing repellent product was applied on surgical wound area (copaiba oil). The process was conducted in 5 minutes.

In order to determine estrus cycle stages and mating occurrence in female paca, after vulvar hygiene, a vaginal sample collection was performed with swabs to analyze cellular components and/or detect sperm presence in smears (Figure 2). This procedure was initiated in G3 on D0, and then every 48 hours until pairing confirmation. For G1 and G2, observations were made every 48 hours until D8, and then every 24 hours until coupling confirmation.

The material obtained from the swabs was analyzed regarding color and texture. Afterwards, the smear was duly carried out by means of identified histological slides, fixed in $95 \%$ alcohol, stained according to the Giemsa technique and examined under a light microscope (Olympus CH30), with 10x and 40x objectives. Convex ultrasound transducer of $7.5 \mathrm{MHz}$ (Aloka, model SSD-500v - Aloka Co. Tokyo, Japan) was performed sixty and ninety days after pairing to confirm gestation.

For obtaining the progesterone levels in the plasma, before and after the implant, blood samples from females were collected $(3 \mathrm{~mL})$ by venipuncture of the cephalic vein, scalps with disposable $21 \mathrm{G}$ and $5 \mathrm{~mL}$ syringes containing EDTA were used.

Properly identified samples were kept refrigerated in ice coolers (maximum 3 hours) until being subjected to centrifugation at $900 \mathrm{~g}$ for 20 minutes. Plasma samples were placed in polypropylene vials and stored at $-20^{\circ} \mathrm{C}$ until measurement. Progesterone concentrations were determined according to the radioimmunoassay described

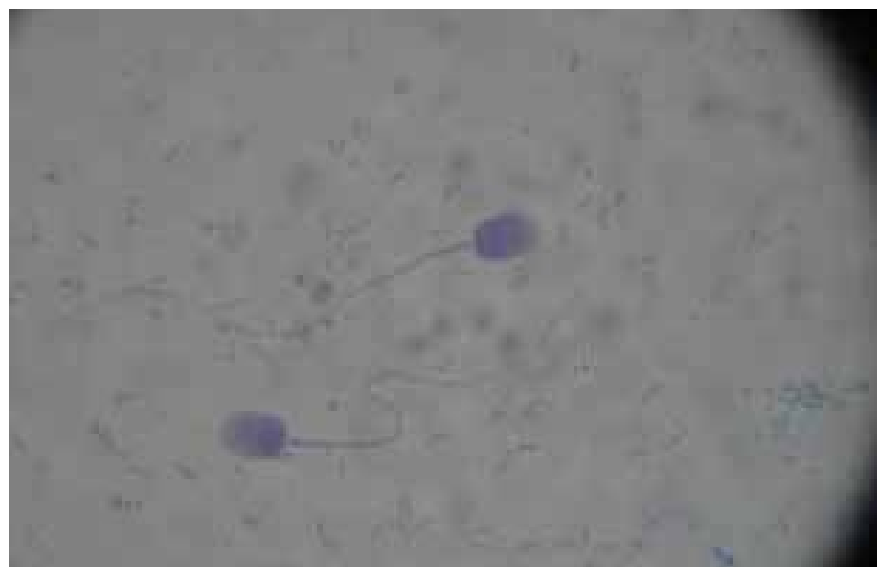

Figure 2 - Spermatozoa of Cubiculum paca in vaginal smear. Experimental Farm Catuaba, University Federal do Acre 
by Knickerbocker et al. (1986), and modified by Carrière and Lee (1994).

The data was analyzed using descriptive statistics and presented as averages, along with their respective standard deviations. Treatment averages were subjected to Anova, adopting a value of $p>0.05$. For this, Excel 2010 and SAS-Statistic Analysis System softwares were used.

\section{Results and Discussion}

In this research, the progestin implant $(1.5 \mathrm{mg}$ Norgestomet) in females of the G1 and G2 groups was effective in the suppression of estrus manifestations and possible ovulation until withdrawal (D8); in G3 females undergoing no treatment, estrus appeared on different days after D0. Comparing estrus appearance in all groups after D0, the statistical difference between treated and untreated females was determined $(\mathrm{p}<0.05)$. However, such difference was not observed in treated groups ( $p>0.05)$.

These data are compliant with Hafez (2004), who stated that among other actions on reproductive physiology progesterone plays a key role in the hormonal regulation of estrous cycle, causing both heat inhibition and preovulatory LH peak, beyond synthetic progestin blockage of LH secretion from pituitaries. Africander et al. (2014) and Mendonça et al. (2007) reported a connection of synthetic progestin to receiver similar to the natural molecule, thereby promoting competition in the binding target. This fact would cause the disruption of the estrous cycle.

Aramburo et al. (2006) managed to induce the estrus cycle in six mountain pacas (Agouti taczanowiskii), a similar species, using 1/4 Norgestomet. The effectiveness of the treatment in the synchronization of three females was noted, considering cycle onset the day of vaginal canal opening. In 12 female animals receiving hormonal treatments, results were adequate because all of them entered estrus. Moreover, 11 (91.66\%) of them were copulated by males, with estrus in G1 in $100 \%$ of the cases $(6 / 6)$, and in G2 in $83 \%$ of the cases (5/6). Due to the lack of similar studies in Cuniculus paca for comparative purposes, outcomes were checked by the physiology of other species.

Some studies with sheep employing similar induction/ synchronization protocols displayed percentages of estrus occurrence ranging from $100 \%$ to $88.5 \%$ (BICUDO; SOUSA, 2003). Their use may also imply such benefits on paca husbandry.

The first female animals manifesting estrus were those receiving $50 \mathrm{IU}$ eCG. For pacas, literature on this topic is nonexistent. In other species, Evans and Robinson (1980) found a negative correlation between the used dosage of eCG and the time of estrus presence after treatment, with a decreasing of 14 hours at higher dosages. Therefore, such differences found in other investigations suggest the need for a broad approach to the determination of whether a contrary and positive effect happens in pacas by increasing eCG dosage.

All G3 females came into estrus, but only in three an effective intercourse was possible. In this case, the pacas may have presented silent heat, that is, hormonal events characterized estrus manifestation, but external signs are not strong enough to be noticed by males. Given these findings, we emphasized that hormonal treatment in G2 and G3 helped heat demonstration and observation by males, which led to an increase of mated and pregnant females in such groups.

The G3 untreated females also developed a shortening of estrous cycle stages, as well as a high estrus manifestation between the first and the thirteenth day of pairing. This behavior seems to indicate a species susceptibility to male effect.

In other species, male presence in a female group can anticipate the start of breeding season (WEIR, 1970) and motivate estrus synchronization through a quick stimulus for GnRH-LH release (MORAES et al., 2008), which can result in various pregnant females at the same time (NOGUEIRA FILHO; NOGUEIRA, 1999; BRIEVA, 2001). However, this effect demands a previous period of sexual isolation (MORAES et al., 2008).

Such conditions have not been applied in this experiment due to its initial design. Nonetheless, we need to identify whether there really is a modulating male effect over heat presentation in this species. Moreover, in the case of such condition presenting itself, a comparison between estrus modulation generated by hormonal treatment and the male effect must to be performed.

The average progesterone concentrations observed in various cycle phases of the paca before hormone implantation were $1.69 \pm 1.26 \mathrm{ng} / \mathrm{mL}$ in proestrus $(\mathrm{n}=4) ; 0.31 \mathrm{ng} / \mathrm{ml}$ in estrus $(\mathrm{n}=1), 1.62 \pm 1.39 \mathrm{ng} / \mathrm{ml}$ in metestrus $(\mathrm{n}=4)$, and $0.88 \pm 0.70 \mathrm{ng} / \mathrm{ml}$ in diestrus $(\mathrm{n}=3)$. These findings, including the large standard deviations, are similar to those described by Guimarães et al. (1999), Pérez (2001) and Pérez and Baz (2006).

Moreover, Reis (2013) measured metabolites in paca feces (Oryctolagus PACA) and noted values ranging 
from 0.37 to $7.9 \mathrm{ng} / \mathrm{g}$ throughout the cycle progestogen. Nevertheless, the progestin fluctuations characteristic of this phase were not present. Ribeiro et al. (2012) compared progesterone levels in chinchillas (Chinchilla laninger Gray, 1831) and found significant changes in hormone concentrations, especially during pregnancy. Likewise, these authors described an increased progesterone concentration during early pregnancy in green acouchi (Myoprocta pratti, Pocock, 1913), which remained beyond the half and declined at the end.

Finally, the average value for progesterone at the implant withdrawal was $1.35 \pm 0.78 \mathrm{ng} / \mathrm{ml}$, with a maximum of $2.87 \mathrm{ng} / \mathrm{ml}$, and a minimum of $0.31 \mathrm{ng} \mathrm{min} / \mathrm{ml}$. Mauer et al. (1975) reported that progesterone-impregnated intravaginal devices increase P4 blood levels in $<1 \mathrm{ng} / \mathrm{ml}$ for $6 \mathrm{ng} / \mathrm{ml}$, within 90 minutes after its insertion, declining from 1 to $3 \mathrm{ng} / \mathrm{ml}$ after 14 days.

Due to the lack of similar reports, the above findings have been comparatively described in other species. Custer et al. (1994), using progesterone-releasing intravaginal device (PRID) in cows, observed an increasing P4 serum concentration of about $25 \%$ twenty-four hours after application, and a progressively declining subluteal phase concentration $(<2 \mathrm{ng} / \mathrm{ml})$ until removal. Sirois and Fortune (1990) obtained P4 from 1 to $2 \mathrm{ng} / \mathrm{ml} \mathrm{P} 4$ after placing, for about nine days, a vaginal insertion device containing progesterone (CIDR-Controlled Internal Drug Release Devices) in heifers.

Cytological analyses showed intermediate cells with nucleoprotein pigments next to estrus expression, as well as

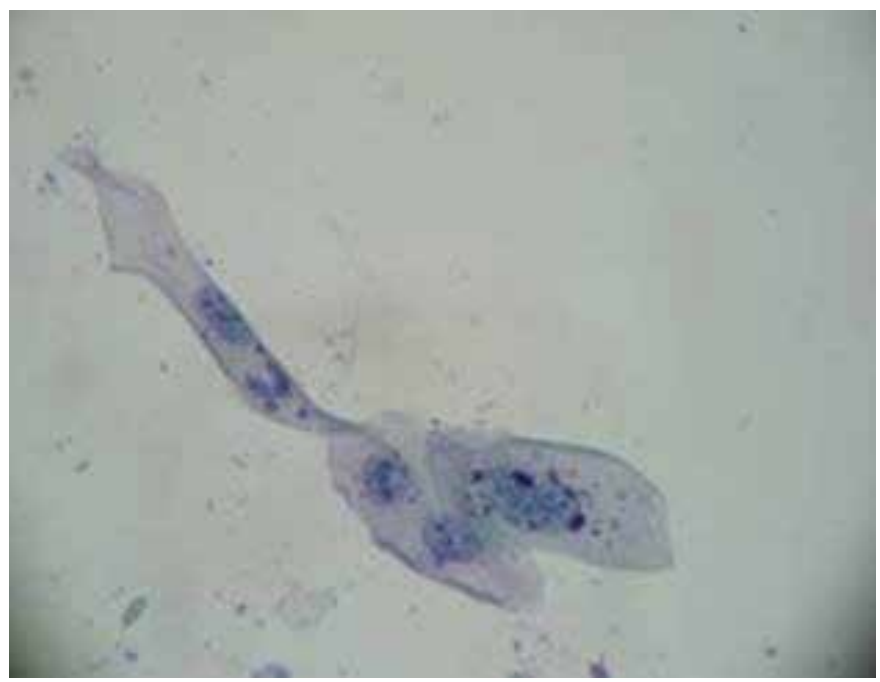

Figure 3 - Intermediate cells with nucleoprotein pigment, Cuniculus paca. Col. Harris-Shorr technical. 400x. Experimental Farm Catuaba, University Federal do Acre intermediate cell pre-ovulatory type (Figures 3 and 4 ). The influence of progesterone and estrogen on the dynamics of exfoliated vaginal cells (EVC) has already been studied in other species (PÉREZ-MARTÍNEZ et al., 1999; RIBEIRO et al., 2007).

Pérez-Martínez et al. (1999) concluded that EVC are highly indicative of progesterone effects, which can be a useful tool to detect hormonal treatment response. These results are consistent with those found in the present research.

Ultrasound and cervical cytology, performed sixty and ninety days after pairing, allowed the identification of six (100\%), four (66\%), and three (50\%) pregnant females in G1, $\mathrm{G} 2$, and G3, respectively. When considering all animal groups, receiving or not treatment, pregnancy rates were $83.3 \%$ and $50 \%$, respectively. Concerning G2, despite the fact that all females displayed estrus, one female was not completely copulated by presenting a low quantity of sperm in the smear test. In the absence of standard references for pacas, results were compared to protocols applied in other animals, which proved being superior to those obtained by Dias et al. (2001), Carrijo Junior and Langer (2006), and Fonseca et al. (2008).

Regarding the female ability to achieve term pregnancy, out of six females from G1, five gave birth and one aborted after completing 90 days of pregnancy. This miscarriage was probably due to its aggressive and irritable behavior not only during parturition, but also to bay peers and handlers.

In G2, the four mated females delivered, but in two of them twin births occurred (Figure 5), giving six babies in total. It means an increase of $50 \%$ on expected births.

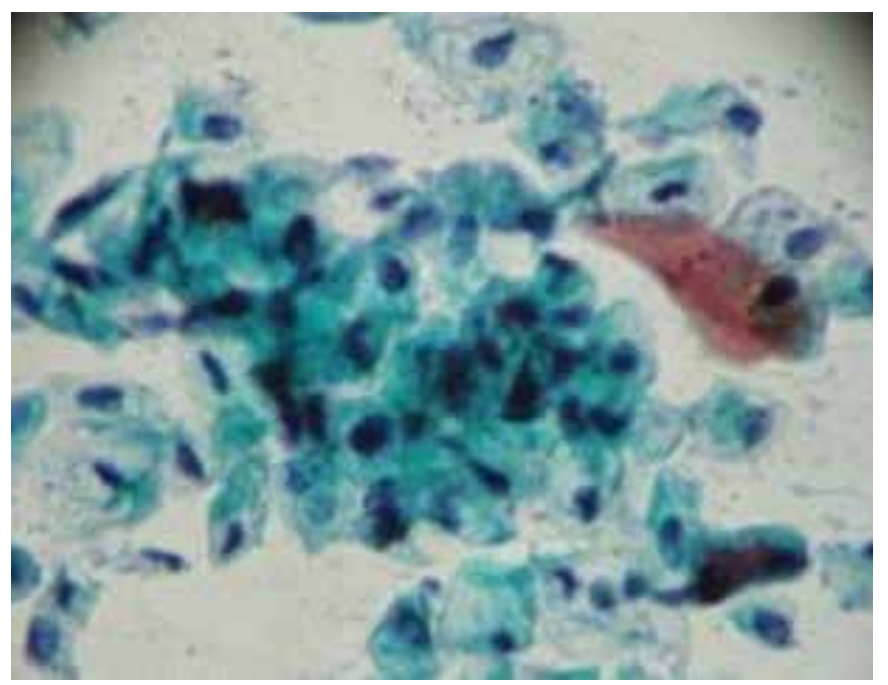

Figure 4 - Pre-ovulatory cells of Cuniculus paca. Col. Harris - Shorr. 400x. Experimental Farm Catuaba, University Federal do Acre 
These results differ from those reported by Nogueira et al. (2006), Oliveira et al. (2007), and Bonilla-Morales et al. (2013), who underscore uniparous reproductive trend of giving one offspring per birth. Therefore, investigating whether there is an association between the applied treatment and multiple births in paca remains as an impending need. Finally, the three paired females from control group (G3) completed the pregnancy term.

The mean and standard deviation for the female gestation period in G1, G2, and G3 were $154( \pm 3.4), 156.75( \pm 2.0)$, and $152.33( \pm 0.47)$ days, respectively. These results are higher than those presented by Bonilla-Morales et al. (2013) - 97 to 101 days; Hosken (1999) - 116-135 days; Colombia (1998) - 120 days; Oliveira et al. (2003) - 135 to 139 days; and similar to Smythe and Guanti (1995) - 157days; Rengifo et al. (1996) - 145 to 155 days; Lameira (2002) - 142-154 days and Guimarães et al. (2008) $-148.6 \pm 4.8$.

Regarding offspring weight at delivery time, outcomes were $860( \pm 134), 716.67( \pm 55)$, and $883.3( \pm 23.5) \mathrm{g}$ for

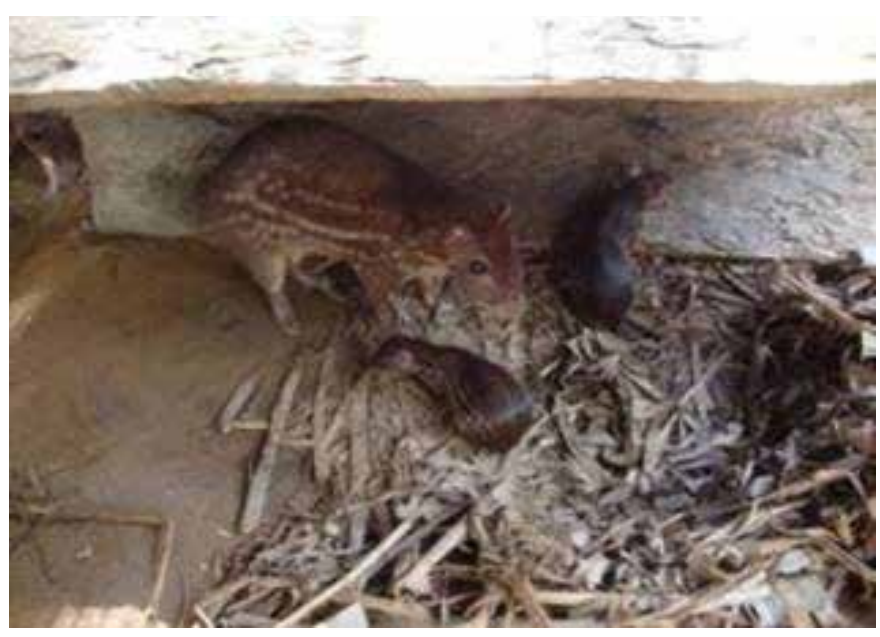

Figure 5 - Paca with twins, born after estrus synchronization and induction (progestin + PGF2a + eCG). Experimental Farm Catuaba, University Federal do Acre

\section{References}

ACRE. Governo do Estado do Acre. Programa Estadual de Zoneamento Ecológico-Econômico do Estado do Acre. Zoneamento Ecológico-Econômico do Acre Fase II: documento síntese - Escala 1:250.000. Secretaria de Estado de Meio Ambiente, Rio Branco, Acre, 2006. $355 \mathrm{p}$.
G1, G2, and G3, respectively. No significant difference (p $>0.05$ ) for birth weight after hormone treatment (25 and $50 \mathrm{IU}$ eCG) was found. However, a significant difference appeared with respect to untreated groups (G3 and G1, G2 and G3) $(p<0.05)$. This fact can be explained by the occurrence of twin births in treated females, giving birth to paca babies with lower weights. Nonetheless, such results were similar to those observed by Guimarães et al. (2008) regarding the average birth weight for females and males: $605.9 \pm 736.7 \pm 108.4$ and 87.5 g, Ribeiro and Zamora (2008), and Oliveira et al. (2007) at $787 \pm 51.23 \mathrm{~g}$ and 741.14 grams, respectively; and superior to Hosken (1999), 500 to $650 \mathrm{~g}$, and Santos et al. (2005), 615 and $617 \mathrm{~g}$ for males and females, respectively.

\section{Conclusion}

The progestin implant in females of G1 and G2 was effective to suppress estrus manifestations and possible ovulation and favored the occurrence of fertile estrus accompanied by physical and behavioral manifestations. Likewise, females treated had higher pregnancy rates and increase of $50 \%$ on expected births. Before such relevant findings as twin birth occurrence, the authors recommend the development of more studies to inquire a possible association between $50 \mathrm{IU}$ eCG dose and this outcome.

\section{Conflict of Interest}

None declared.

\section{Acknowledgement}

The authors want to thank to the Government of the State of Acre, especially Dr. Mauro Ribeiro, Agriculture Secretary, Maria do Carmo Portela, Veterinary Doctor, and Ciro Moraes Barros, Professor of Pharmacology Laboratory of Reproduction of UNESP/Botucatu - São Paulo.

AFRICANDER, D. J.; STORBECK, K. H.; HAPGOOD, J. P. A comparative study of the androgenic properties of progesterone and the progestins, medroxyprogesteroneacetate (MPA) and norethisterone acetate (NET-A). The Journal of Steroid Biochemistry and Molecular Biology, v. 143, p. 404-415, 2014. doi: 10.1016/j.jsbmb.2014.05.007. 
ARAMBURO, L. E. T.; RESTREPO, G. H.; PÉREZ, C. G.; GÓMEZ, J. R. Synchronous induction of the estral cycle in the black guagua (Agouti taczanowskii) in captivity. Revista Facultad Nacional de Agronomía Medellín, v. 59, n. 1, p. 3281-3293, 2006.

BICUDO, S. D.; SOUSA, D. B. Association of progestagen, prostaglandin and eCG in short-term protocol of estrus induction/synchronization on Suffolk ewes. Revista Brasileira de Reprodução Animal, v. 27, n. 3, p. 473-474, 2003.

BONILLA-MORALES, M. M.; PULIDO, J. R.; PACHECO, R. M. Biology of agouti (Cuniculus paca Brisson): a breeding perspective. Revista CES Medicina Veterinaria y Zootecnia, v. 8, n. 1, p. 82-95, 2013.

BRIEVA, C. B. Borugos (Agoutipaca e Agouti taczanowiskii). Boletin del grupo de estúdio de animais silvestres. Boletin GEAS, v. 1, n. 2, 2001.

CARRIÈRE, P. D.; LEE, B. Direct radioimmunoassay of progesterone in bovine plasma using danazol (17-alpha-2,4pregnadien-20-yno(2,3-d)isoxazol-17-ol) as a displacing agent. Canadian Journal of Veterinary Research, v. 58, n. 3, p. 230-233, 1994.

CARRIJO JUNIOR, O. A.; LANGER, J. Evaluating a controlled artificial insemination protocol using eCG (PMSG) in Pure Bred and calved Nelore cows. Revista Electrónica de Veterinaria, v. 7, n. 2, 2006.

COLOMBIA. Corporación Colombiana de Investigación Agropecuaria. Programa Nacional de Transferencia de Tecnología Agropecuaria. Instituto Amazónico de Investigaciones Científicas. Cria y manejo de boruga Agouti paca en cautiverio en areas de colonización consolidada de Caquetá como contribución al uso sostenible de la biodiversidad amazónica. Florencia: Corporación Colombiana de Investigación Agropecuaria, 1998.

CUSTER, E. E.; BEAL, W. E.; WILSON, S. J.; MEADOWS, A. W.; BERARDINELLI, J. G.; ADAIR, R. Effect of melengestrol acetate (MGA) or progesterone-releasing intravaginal device (PRID) on follicular development, concentrations of estradiol-17 beta and progesterone, and luteinizing hormone release during an artificially lengthened bovine estrous cycle. Journal of Animal Science, v. 72, n. 5, p. 1282-1289, 1994.

DIAS, F. E. F.; JUNIOR, E. S. L.; VILLAROEL, A. B. S.; RONDINA, D.; LIMA-VERDE, J. B.; PAULA, N. R. O.; FREITAS, V. J. F. Estrus synchronization, ovulation induction and fertility in hairless ewes treated with equine chorionic gonadotrophin. Arquivo Brasileiro de Medicina Veterinária e Zootecnia, v. 2001, n. 5, p. 618-623, 2001. doi: 10.1590/S0102-09352001000500018.

EVANS, G.; ROBINSON, T. J. The control of fertility in sheep: endocrine and ovarian responses to progestagenPMSG treatment in the breeding season and in anoestrus. The Journal of Agricultural Science, v. 94, n. 1, p. 69-88, 1980. doi: 10.1017/S002185960002791X.

FONSECA, J. F.; TORRES, C. A.; SANTOS, A. D.; MAFFILI, V. V.; AMORIM, L. S.; MORAES, E. A. Progesterone and behavioral features when estrous is induced in Alpine goats. Animal Reproduction Science, v. 103, p. 366-373, 2008. doi: 10.1016/j.anireprosci.2007.05.013.

GUIMARÃES, D. A.; BASTOS, L. V.; FERREIRA, A. C. S.; LUZ-RAMOS, R. S.; OHASHI, O. M.; RIBEIRO, H. L. Reprodutive characteristics of the female paca (Agouti paca) raised in captivity. Acta Amazonica, v. 38, n. 3, p. 531-538, 2008. doi: 10.1590/S0044-59672008000300019.

GUIMARÃES, D. A.; LAMEIRA, A. P. G.; OHASHI, O. M. Perfil hormonal de progesterona no ciclo estral da Agouti paca - estudo preliminar. In: CONGRESO INTERNACIONAL DE MANEJO DE FAUNA SILVESTRE, 4., 1999, Asunción. Proceedings... Asunción: CITES, 1999. p. 117-118.

HAFEZ, E. S. E. Anatomia funcional da reprodução feminina. In: HAFEZ, E. S. E.; HAFEZ, B. Reprodução animal. 7. ed. São Paulo: Manole, 2004. p. 13-29.

HOSKEN, F. M. Criação de pacas. Cuiabá: SEBRAE/MT, 1999. $171 \mathrm{p}$.

JAINUDEEN, M. R.; WAHID, H.; HAFEZ, E. S. E. Indução da ovulação, produção e transferência de embriões. In: HAFEZ, E. S. E.; HAFEZ, B. Reprodução animal. 7. ed. São Paulo: Manole, 2004. p. 409-434. 
KNICKERBOCKER, J. J.; THATCHER, W. W.; BAZER, F. W.; DROST, M.; BARRON, D. H.; FICHER, K. B.; ROBERTS, R. M. Proteins secreted by Day -16 to -18 bovine conceptuses extend corpus luteum function in cows. The Journal of the Society for Reproduction and Fertility, v. 77, p. 381-391, 1986. doi: 10.1530/jrf.0.0770381.

\section{LAMEIRA, A. P. G. Determinação de alguns parâmetros} da biologia reprodutiva e produtiva da paca fêmea (Agouti paca, Linnaeus 1744) criada em cativeiro. 2002. 49 f. Dissertação (Mestrado em Zoologia) - Museu Paraense Emílio Goeldi, Universidade Federal do Pará, Belém, 2002.

MAIA JÚNIOR, A. Indução e sincronização do estro e da ovulação em cabras leiteiras saanen com uso de dispositivos vaginais associados ou não à eCG ou efeito macho. 2009. 77 f. Dissertação (Mestrado em Reprodução e Sanidade Animal) - Faculdade de Veterinária, Universidade Estadual do Ceará, Fortaleza, 2009.

MAUER, R. E.; WEBEL, S. K.; BROWN, M. D. Ovulation control in cattle with progesterone intravaginal device (PRID) and gonadotropin releasing hormone (GnRH). Annales de Biologie Animale, Biochimie, Biophysique, v. 15, n. 2, p. 291-296, 1975. doi: 10.1051/rnd:19750216.

MAYOR, P.; GUIMARÃES, D. A.; LÓPEZ, C. Functional morphology of the genital organs in the wild paca (Cuniculus paca) female. Animal Reproduction Science, v. 140, n. 3-4, p. 206-215, 2013. doi: 10.1016/j.anireprosci.2013.06.010.

MELLO, N. M.; PINTO-NETO, A. Oestrus synchronization using craft and comercial device progestin in Nelore cows. Arquivos de Ciências Veterinárias e Zoologia da UNIPAR, v. 12, n. 2, p. 191-192, 2009.

MENDONÇA, F. S.; EVÊNCIO-NETO, J.; SIMÕES, M. J.; CAMARGO, L. M.; BARATELLA-EVÊNCIO, L. Cytopathological aspects of female mices vaginal mucosa treateds with medroxyprogesterone. Ciência Animal Brasileira, v. 8, n. 2, p. 313-318, 2007. doi: 10.5216/cab. v8i2.1356.

MONREAL, A. C. D.; CARNEIRO, L. O. H. B.; REDONDO, M. V. S. Male effect associated with employment of intravaginal progesterone in sheep, in latitude $20^{\circ} 52^{\prime}$ south. Revista Agrarian, v. 2, n. 4, p. 143-152, 2009.

MONREAL, A. C. D.; TONIOLLO, H. G.; ZORZATTO, J. R.; BICUDO, S. D. Goats synchronized with CIDR bellow latitude 20²8'S. Revista Archivos de Zootecnia, v. 51, n. 196, p. 453-456, 2002.

MONTES, R. El tepezcuintle, un recurso biológico importante. Conabio Biodiversitas, v. 63, p. 6-11, 2005.

MORAES, J. C. F.; SOUZA, C. J. H.; GONÇALVES, P. B. D.; FREITAS, V. J. F.; LOPES JÚNIOR E. S. Controle do estro e da ovulação em ruminantes. In: GONÇALVES, P. B. D.; FIGUEIREDO, J. R.; FREITAS, V. J. F. Biotécnicas aplicadas à reprodução animal. 2. ed. São Paulo: Roca, 2008. p. 33-55.

MOREIRA, R. J. C.; PIRES, A. V.; MALUF, D. Z.; MADUREIRA, E. H.; BINELLI, M.; GONÇALVES, J. R.; LIMA, L. G.; SUSIN, I. Sincronization of ovulation utilizing the Crestar ${ }^{\circledast}$ protocol associated with estradiol benzoate, PGF2 $\alpha$, PMSG and GnRH in beef cows. Brazilian Journal of Veterinary Research and Animal Science, v. 44, n. 1, p. 56-62, 2007. doi: 10.11606/issn.1678-4456. bjvras.2007.26662.

NOGUEIRA, D. M.; LOPES JÚNIOR, E. S.; BORGES, G. S.; MONTE, A. P. O.; MARTINS, S. R. Estrus activity of dairy goats raised in the semi-arid zone of northeastern Brazil using different estrus synchronization protocols. In: CONGRESSO NORDESTINO DE PRODUÇÃO ANIMAL, 5., 2008. Proceedings... Aracaju: Sociedade Nordestina de Produção Animal, 2008.

NOGUEIRA, T. M. R.; GIANNONI, M. L.; TONIOLLO, G. H. Observações preliminares sobre a reprodução de uma colônia de pacas Agouti paca Linnaeus, 1766 em cativeiro. Estudos Econômicos e Agropecuários, v. 6, n. 25, p. 83-95, 2006.

NOGUEIRA FILHO, S. L. G.; NOGUEIRA, S. S. C. Criação de pacas (Agouti paca). Piracicaba: Fundação de Estudos Agrários Luiz de Queiroz, 1999. 70 p.

OLIVEIRA, F. S.; MACHADO, M. R. F.; CANOLA J. C. Real time B-mode ultrasound in pacas pregnancy (Agouti 
paca, Linnaeus, 1776). Brazilian Journal of Veterinary

Research and Animal Science, v. 40, n. 1 p. 73-78, 2003. doi: 10.1590/S1413-95962003000100009.

OLIVEIRA, F. S.; MACHADO, M. R. F.; CANOLA, J. C.; CAMARGO, M. H. B. Uniparity in pacas bred in captivity (Agouti paca, Linnaeus, 1766). Arquivo Brasileiro de Medicina Veterinária e Zootecnia, v. 59, n. 2, p. 387-389, 2007. doi: 10.1590/S010209352007000200019 .

PÉREZ, R. C. M.; BAZ, E. A. C. Ovarian activity of Agouti paca (Rodentia: Agoutidae) under captivity. Revista de Biología Tropical, v. 54, n. 3, p. 903-910, 2006. doi: 10.15517/rbt.v54i3.13687.

PÉREZ-MARTÍNEZ, M.; MENDOZA, M. E.; ROMANO, M. C. Exfoliative vaginal cytology and plasma levels of estrone and estradiol-17 $\beta$ in young and adult goats. Small Ruminant Research, v. 33, n. 2, p. 153-158, 1999. doi: 10.1016/S0921-4488(99)00008-5.

PÉREZ, R. C. M. Caracterização de la atividade reprodutiva de tepezcuitle (Agouti paca) bajo crianza controlada. Informe final do proyecto. Universidade Autónoma de Yucatan Facultad de Medicina Veterinária y Zootecnia. México, 9 pp. 2001.

REIS, A. C. G. Determinação dos perfis de estrógenos e progestinas fecais durante o ciclo estral e gestação em paca (Cuniculus paca). 2013. 65 f. Tese (Doutorado em Cirurgia Veterinária) - Faculdade de Ciências Agrárias e Veterinárias, Universidade Estadual Paulista, Jaboticabal, 2013.

RENGIFO, P. M. E.; NAVARRO, T. D.; URRUNAGA, B. A.; VÁSQUEZ, F. W.; ASPAJO, V. F. Crianza familiar del majaz o paca (Agouti paca) en la Amazonia. Lima: Secretaría Pro Tempore del Perú, 1996. 45 p.

RIBEIRO, A. P. C.; VICENTE, W. R. R.; SANTOS, I. W.; PIRES, E. A.; ALVES, A. E.; APPARÍCIO, M. F. Gonadotrophin in the induction of estrus in bitches.
Revista Brasileira de Saúde e Produção Animal, v. 8, n. 4, p. 324-334, 2007.

RIBEIRO, V. M. F.; RUMPF, R.; SATRAPA, R.; SATRAPA, R. A.; RAZZA, E. M.; CARNEIRO JUNIOR, J. M.; PORTELA, M. C. Vaginal citology, serum progesterone concentration during pregnancy and fetal measurements in paca (Cuniculus paca, Linnaeus 1766). Acta Amazonica, v. 42, n. 3, p. 445454, 2012. doi: 10.1590/S0044-59672012000300018.

RIBEIRO, V. M. F.; ZAMORA, L. M. Pacas e capivaras: criação em cativeiro com ambientação natural. Rio Branco: Bagaço, 2008. 48 p.

ROCHA, J. M.; RABELO, M. C.; SANTOS, M. H. B.; MACHADO, P. P.; BARTOLOMEU, C. C.; NEVES, J. P.; LIMA, P. F.; OLIVEIRA, M. A. L. AIFT in Nelore cows: evaluation of two eCG dose and reutilization of intravaginal device of progesterone. Medicina Veterinária, v. 1, n. 1, p. 40-47, 2007.

SANTOS, R.; LIMA, A. L.; BARBOSA, W. A.; VARGAS VARGAS JUNIOR, J. G. In: Encontro Latino Americano de Iniciação Científica, 9., 2005, São José dos Campos. Proceedings... São José dos Campos: Universidade do Vale do Paraíba, 2005.

SCHERF, B. D. Lista mundial de vigilancia para la diversidad de los animales domésticos. 2 ed. Roma: FAO, 1997. $777 \mathrm{p}$.

SIROIS, J.; FORTUNE, J. E. Lengthening the bovine estrous cycle with low levels of exogenous progesterone: a model for studying ovarian follicular dominance. Endocrinology, v. 127, n. 2, p. 916-925, 1990. doi: 10.1210/endo-127-2-916.

SMYTHE, N.; GUANTI, O. B. La domesticación y cria de la paca (Agouti paca). Guia FAO conservación, 26. Roma: FAO, 1995.

WEIR, B. J. The management and breeding of some more hystricomorph rodents. Laboratory Animals, v. 4, p. 8397, 1970. doi: 10.1258/002367770781036562. 